\title{
ANALISIS DISPARITAS EKONOMI DAERAH PESISIR PULAU JAWA
}

\author{
Atika Fatimah \\ Universitas AMIKOM Yogyakarta \\ email : atika.fatimah@amikom.ac.id
}

\begin{abstract}
ABSTRAK
Penelitian ini bertujuan untuk mengetahui nilai disparitas ekonomi daerah pesisir utara dan selatan Pulau Jawa. Pendekatan penelitian yang digunakan adalah kuantitatif. Data penelitian yang digunakan adalah data sekunder berupa PDRB provinsi dan kabupaten serta jumlah penduduk. Metode analisis data yang digunakan untuk menghitung nilai disparitas ialah Indeks Entropi Theil. Hasil penelitian adalah rata-rata nilai Indeks Enthropi Theil daerah pesisir utara Pulau Jawa sebesar 0,0261 dan daerah pesisir selatan sebesar 0,0085. Hal ini mengindikasikan bahwa daerah pesisir selatan lebih merata daripada pesisir utara Pulau Jawa karena nilai Indeks Entropi Theilnya lebih kecil.
\end{abstract}

Kata kunci : disparitas, daerah pesisir, Pulau Jawa, Indeks Entropi Theil

\section{ABSTRACT}

This research aim to determine the value of economic disparity in the northern and southern coastal Java Island. The approach of research is quantitative. The data of research is secondary data which is consist of provincial and district GRDP and total population. The analysis method used to calculate the value of disparity is Entropy Theil Index. The results of the research is average value of Entropi Theil Index in the northen coastal Java Island at 0,0085. This indicates that the southern coastal is more distributed than the northen coastal of Java Island because the value of Entropi Theil Index is smaller.

Keywords : disparity, coastal, Java Island, Entropi Theil Indeks

\section{PENDAHULUAN}

\subsection{Latar Belakang}

Pertumbuhan ekonomi yang tinggi pada suatu negara selalu menyisakan masalah klasik yakni ketimpangan atau disparitas ekonomi. Menurut data World Bank, sejak tahun 2000 ketimpangan ekonomi meningkat pesat karena pertumbuhan ekonomi hanya dinikmati oleh $20 \%$ penduduk terkaya daripada penduduk umum lainnya (Tjoe, 2018). Dua puluh tahun lalu pertumbuhan ekonomi yang berkelanjutan di Indonesia telah membantu mengurangi kemiskinan dan menciptakan kelas menengah yang tumbuh. Tingkat disparitas Indonesia sekarang dianggap relatif tinggi karena naik lebih cepat dari sebagian besar negara tetangga di Asia Timur.

Pada tahun 2003 dan 2010, konsumsi per orang untuk 10\% orang kaya Indonesia tumbuh lebih dari $6 \%$ per tahun setelah disesuaikan dengan inflasi. Tetapi untuk $40 \%$ penduduk termiskin, konsumsi tumbuh kurang dari 2\% per tahun (The World Bank, 2015). Alhasil terjadi peningkatan tajam koefisien gini dari tahun 2003 ke tahun 2010. Untuk tahun 2019 gini ratio Indonesia sebesar 0,382 berarti berarti Indonesia masih berada dalam kategori mendekati merata. Namun terjadi sebuah fenomena selama 5 tahun belakangan yakni menurut data gini ratio Pulau Jawa selalu diatas rata-rata nasional selama tahun 2015 hingga 2019 sesuai dengan grafik perbandingan gini ratio Indonesia dan Pulau Jawa berikut, 


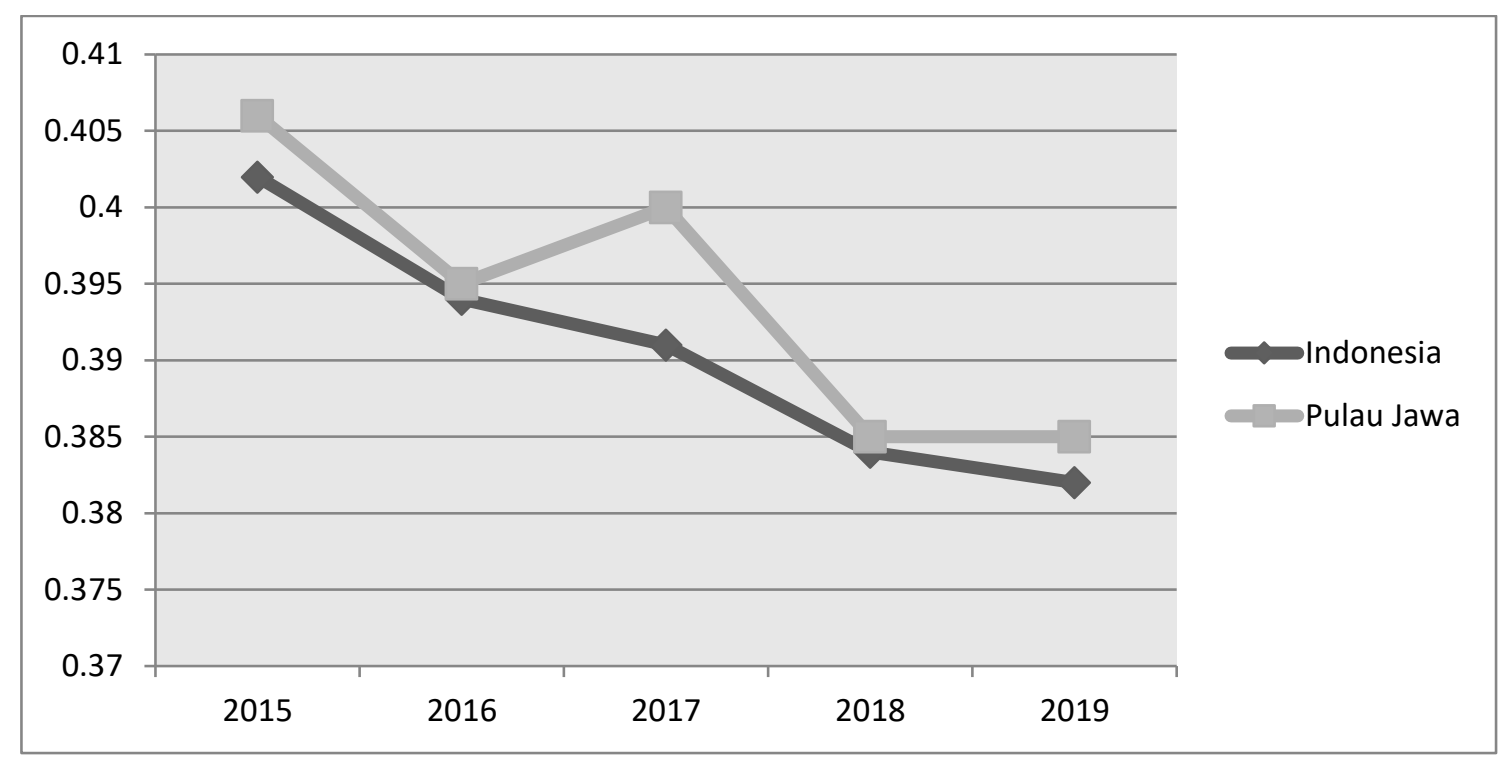

Sumber : Data BPS diolah, 2019

Gambar 1. Grafik Perbandingan Gini Ratio Indonesia dan Pulau Jawa, 2015-2019

Tingginya angka indeks gini di Pulau Jawa pada grafik diatas menunjukkan bahwa ketimpangan ekonomi yang terjadi masih tinggi padahal Pulau Jawa merupakan salah satu roda penggerak perekonomian nasional karena sebagian besar daerah maju daerah yang berada disini. Oleh sebab itu perlu dilihat permasalahan disparitas yang terjadi di Pulau Jawa dari sisi ketimpangan distribusi pendapatan, ketimpangan antarwilayah atau ketimpangan antargender.

Berdasarkan penelitian Thomas Nugroho (2004), ketimpangan di Pulau Jawa terjadi antarwilayah pesisir yakni utara dan selatan di Provinsi Jawa Barat yang menyatakan ketimpangan pembangunan yang terjadi antarwilayah disebabkan oleh polarisasi wilayah penempatan investasi seperti pembangunan infrastruktur. Hal ini diperkuat oleh pernyataan Miranti yakni daerah pesisir utara pulau Jawa lebih maju dari daerah pesisir selatan Pulau Jawa. Hal ini disebabkan oleh adanya jalur pantura pada daerah pesisir utara yang menjadi nadi utama transportasi darat karena dilewati 20.000-70.000 kendaraan. Adanya jalur pantura menyebabkan pertumbuhan industri yang padat pada daerah pesisir utara sehingga menghasilkan pertumbuhan ekonomi yang baik bagi daerah pesisir utara (Miranti, 2017).

Sebaliknya, daerah pesisir pantai selatan sangat rawan bencana terutama gelombang tinggi Laut Jawa yang menyebabkan pembangunan infrastruktur tidak sepesat pada daerah pesisir utara. Hal ini tentu mengakibatkan rendahnya pertumbuhan ekonomi pada wilayah kabupaten yang dilewatinya karena akses infrastruktur yang sulit menyebabkan pertumbuhan ekonomi tidak setinggi daerah pesisir Pulau Jawa. Berdasarkan fakta dan temuan sebelumnya diatas maka peneliti ingin mengetahui besarnya ketimpangan atau disparitas ekonomi daerah pesisir utara dan selatan Pulau Jawa.

\section{KAJIAN LITERATUR}

\subsubsection{Kesenjangan Regional}

Dalam konstelasi perkembangan terakhir di Indonesia, kesenjangan ekonomi dilihat dari tiga dimensi yaitu,

- Tingkat kemodernan yaitu kesenjangan antara sektor modern dan tradisional. Sektor modern umumnya berada diperkotaan dan sedangkan sektor tradisional umumnya berada di perdesaan dan sektor pertanian 
- Regional adalah kesenjangan pembangunan antarwilayah seperti infrastruktur dan pusat kegiatan wilayah yang diakibatkan oleh pengurasan sumber daya oleh daerah yang lebih maju dan berpindahnya penduduk usia produktif dari daerah yang kurang maju

- Etnis yakni kesenjangan antara pribumi dengan nonpribumi

\subsubsection{Teori Kutub Pertumbuhan (Growth Pole Theory)}

Teori yang dikemukakan oleh Francois Perroux ini menyatakan bahwa pembangunan sebuah kota atau wilayah merupakan hasil dari sebuah proses yang tidak bisa dilakukan secara serentak melainkan muncul di tempat-tempat tertentu dengan kecepatan dan intensitas berbeda. Tempat yang menjadi pusat pembangunan atau pengembangan disebut kutub pertumbuhan. Dari kutub-kutub ini, proses pembangunan akan menyebar ke wilayah-wilayah lain dan sekitarnya atau ke pusat-pusat yang lebih rendah. Dalam teori ini dikenal dengan istilah yang berkaitan dengan timbulnya dampak positif dan negatif dari interaksi kutub pertumbuhan dengan daerah sekitarnya. Dampak positif dari kemajuan pembangunan dari pusat pembangunan disebut dengan trickle-down effect. Dampak negatif yang dirasakan oleh wilayah pinggiran disebut dengan backwash polarization. Proses pembangunan yang menyebar bertujuan untuk meningkatkan investasi pada satu kota tertentu yang diharapkan selanjutnya meningkatkan aktivitas kota sehingga akan semakin lebih banyak lagi melibatkan penduduk dan pada akhirnya semakin banyak barang dan jasa yang dibutuhkan.

\subsubsection{Teori Tempat Sentral}

Teori ini dikemukakan oleh Walter Christaller yang didasarkan pada lokasi dan pola persebaran pemukiman dalam ruang. Dalam suatu ruang kadang ditemukan persebaran pola pemukiman desa dan kota yang berbeda ukuran luasnya. Jadi cara terbaik untuk menjadikan suatu wilayah sebagai pusat pertumbuhan ialah menempatkan aktivitas utama pada hirarki pemukiman yang luasnya semakin meningkat serta berada pada simpul-simpul jaringan heksagonal. Lokasi yang dimaksud terdapat pada tempat sentral yang memungkinkan partisipasi manusia dengan jumlah banyak baik yang terlibat dalam aktivitas produksi maupun menjadi konsumen dari barang-barang yang dihasilkan. Tempat sentral ini diasumsikan sebagai titik simpul dari suatu geometris berdiagonal yang memiliki pengaruh terhadap daerah sekitarnya. Hubungan antara suatu tempat sentral terhadap dengan tempat sentral yang lain disekitarnya membentuk jaringan sarang lebah.

Menurut Walter Christaller, suatu tempat sentral mempunyai batas-batas pengaruh yang melingkar dan komplementer terhadap tempat sentral tersebut. Daerah atau wilayah yang komplementer adalah daerah yang dilayani oleh tempat sentral. Lingkaran batas yang ada pada Kawasan pengaruh tempat-tempat sentral disebut batas ambang (threshold level).

\subsubsection{Teori Resources Endowment}

Teori ini menyatakan bahwa pengembangan ekonomi bergantung pada sumber daya alam yang dimiliki dan permintaan terhadap komoditas yang dihasilkan dari sumber daya tersebut.

\subsubsection{Penelitian Terdahulu}

Menurut Ohlan (2013), Indeks pembangunan sosial ekonomi yang dibangun menunjukkan bahwa wilayah selatan India jauh lebih berkembang secara simetris dibandingkan wilayah tengah dan utara. Hasil penelitiannya juga menunjukkan bahwa pada wilayah utara dan tengah India, perkembangan sektor industrinya tidak berpengaruh signifikan pada kondisi pembangunan sosial ekonomi secara keseluruhan di India namun yang berpengaruh adalah sektor pertanian.

Christofakis (2019) mengungkapkan bahwa terdapat kesenjangan yang meningkat di Yunani selama periode pertama krisis pada tahun 2000. Pada periode pertama ini terdapat konsentrasi sektor ekonomi yang dinamis pada wilayah metropolitan Attica dan Pulau Aegean 


\section{4 | Bina Ekonomi}

Selatan. Kemudian pada periode selama krisis wilayah ini kehilangan dinamisme sektor unggulannya.

\subsubsection{State of The Arts}

State of The Arts memiliki definisi ukuran tingkat pengembangan yang dicapai pada waktu tertentu sebagai hasil dari penerapan metodologi-metodologi yang ada (Narutomo, 2015). Metode analisis data yang digunakan adalah Indeks Entropi Theil yang tidak terlalu lazim digunakan untuk mengukur disparitas ekonomi. Pada umumnya untuk pengukuran disparitas ekonomi menggunakan Indeks Williamson namun pada penelitian saya menggunakan Indeks Entropi Theil yang dikhususnya untuk mengukur ketimpangan antarwilayah.

\section{METODE PENELITIAN}

Data yang digunakan adalah data sekunder yakni PDRB Provinsi, PDRB Kabupaten dan jumlah penduduk pada tahun 2016. Data sekunder ini dikumpulkan dengan dokumentasi yakni pengambilan data melalui dokumen tertulis dan elektronik dari lembaga atau institusi.

Metoda analisis data yang digunakan untuk mengukur disparitas daerah pesisir utara dan selatan pulau Jawa adalah Indeks Enthropi Theil. Indeks Enthropi Theil merupakan salah satu alat analisis yang digunakan untuk melihat besar kecilnya angka ketimpangan yang terjadi. Indeks Enthropi Theil memiliki formulasi yakni,

$$
\mathrm{T}=\sum_{i=j}^{n} \sum_{j=1}^{n}\left(\frac{y_{i j}}{Y_{i}}\right) \log \left(\frac{y_{i j} / Y_{i}}{n_{i j} / N_{i}}\right)
$$

keterangan :

$\mathrm{T}$ : Indeks Enthropi Theil

$\mathrm{y}_{\mathrm{ij}}$ : PDRB per kapita daerah kecamatan kota i pada provinsi $\mathrm{j}$

$Y_{\mathrm{i}}$ : PDRB di provinsi $\mathrm{j}$

Menurut Sjafrizal (2018), derivasi matematis perhitungan ketimpangan ekonomi dalam wilayah (within) dan antarwilayah (between) adalah sebagai berikut.

$$
\begin{gathered}
\mathrm{T}=\sum_{i=1}^{n}\left(\frac{y_{i}}{Y}\right) T_{d}+\sum_{i=1}^{n}\left(\frac{y_{i}}{Y}\right) \log \left(\frac{y_{i} / Y}{n_{i} / N}\right) \\
\mathrm{T}=\sum_{i=1}^{n}\left(\frac{y_{i}}{Y}\right) T_{d}+T_{B R} \ldots \ldots \ldots \ldots \ldots \ldots \ldots \ldots \ldots \ldots \ldots \ldots \ldots \ldots \ldots \ldots \ldots \ldots \ldots \ldots \ldots \ldots \ldots
\end{gathered}
$$

Persamaan diatas menunjukkan bahwa indeks ketimpangan regional $\mathrm{T}$ dapat diuraikan (decomposed) menjadi dua bagian yaitu ketimpangan dalam daerah ( $\mathrm{T}_{\mathrm{WR}}$ ) dan ketimpangan antardaerah $\left(\mathrm{T}_{\mathrm{BR}}\right)$ dimana,

$$
\begin{array}{r}
\mathrm{T}_{\mathrm{BR}}=\sum_{i=1}^{n}\left(\frac{y_{i}}{Y}\right) \log \left(\frac{y_{i} / Y}{n_{i} / N}\right) \ldots \ldots \\
\mathrm{dan} \\
\mathrm{T}_{\mathrm{WR}}=\sum_{i=1}^{n}\left(\frac{y_{i}}{Y}\right) T_{d} \ldots \ldots \ldots \ldots \ldots
\end{array}
$$

Selain Indeks Enthropi Theil, penelitian ini juga menggunakan uji Kolmogorov-Smirnov dan paired sample t-test sebagai metode analisis data. Uji Kolmogorov-Smirnov digunakan untuk mengetahui kenormalan distribusi beberapa data. Hipotesis pada uji Kolmogorov-Smirnov adalah sebagai berikut,

$\mathrm{H}_{0}$ : data mengikuti distribusi yang ditetapkan

$\mathrm{H}_{1}$ : data tidak mengikuti distribusi yang ditetapkan

Uji Kolmogorov-Smirnov lebih kuat dari pada uji chi-square ketika asumsi-asumsinya terpenuhi. Hal ini disebabkan oleh beberapa hal yakni,

a. Uji chi-square memerlukan data yang berkelompok sedangkan uji Kolmogorov-Smirnov tidak 
b. Uji chi-square tidak bisa untuk sampel kecil sedangkan uji Kolmogorov-Smirnov bisa

c. Data chi-square bersifat ketegorial sehingga ada data yang terbuang maknanya

d. Uji Kolmogorov-Smirnov lebih fleksibel dibanding uji chi-square

Tidak hanya uji Kolmogorov-Smirnov, normalisasi distribusi data juga bisa diuji dengan paired sample t-test yakni uji yang menunjukkan apakah sampel berpasangan mengalami perubahan yang bermakna. Hasil uji paired sample t-test ditentukan oleh nilai signifikansinya yang kemudian akan menentukan keputusan yang diambil dalam penelitian. Jika nilai signifikansi < 0,05 menunjukkan adanya perbedaan yang signifikan antara variabel awal dengan variabel akhir sehingga terdapat pengaruh yang bermakna terhadap perbedaan perlakuan yang diberikan pada masing-masing variabel. Sedangkan jika nilai signifikansi $>0,05$ menunjukkan tidak terdapat perbedaan yang signifikan antara variabel awal dengan variabel akhir sehingga tidak terdapat pengaruh yang bermakna terhadap perbedaan perlakuan yang diberikan pada masing-masing variabel.

\section{HASIL PENELITIAN}

\subsection{Analisis Hasil Indeks Entropi Theil Daerah Pesisir Utara Pulau Jawa}

Daerah pesisir utara Pulau Jawa terbentang sejauh $1316 \mathrm{~km}$. Pesisir pulau Jawa terdiri atas 29 kabupaten yang berasal dari 5 provinsi di Pulau Jawa yakni provinsi DKI Jakarta, Banten, Jawa Barat, Jawa Tengah dan Jawa Timur. Untuk mengetahui tinggi rendahnya Indeks Entropi Theil pada masing-masing kabupaten/kota di daerah pesisir utara Pulau Jawa dapat dilihat pada grafik berikut.

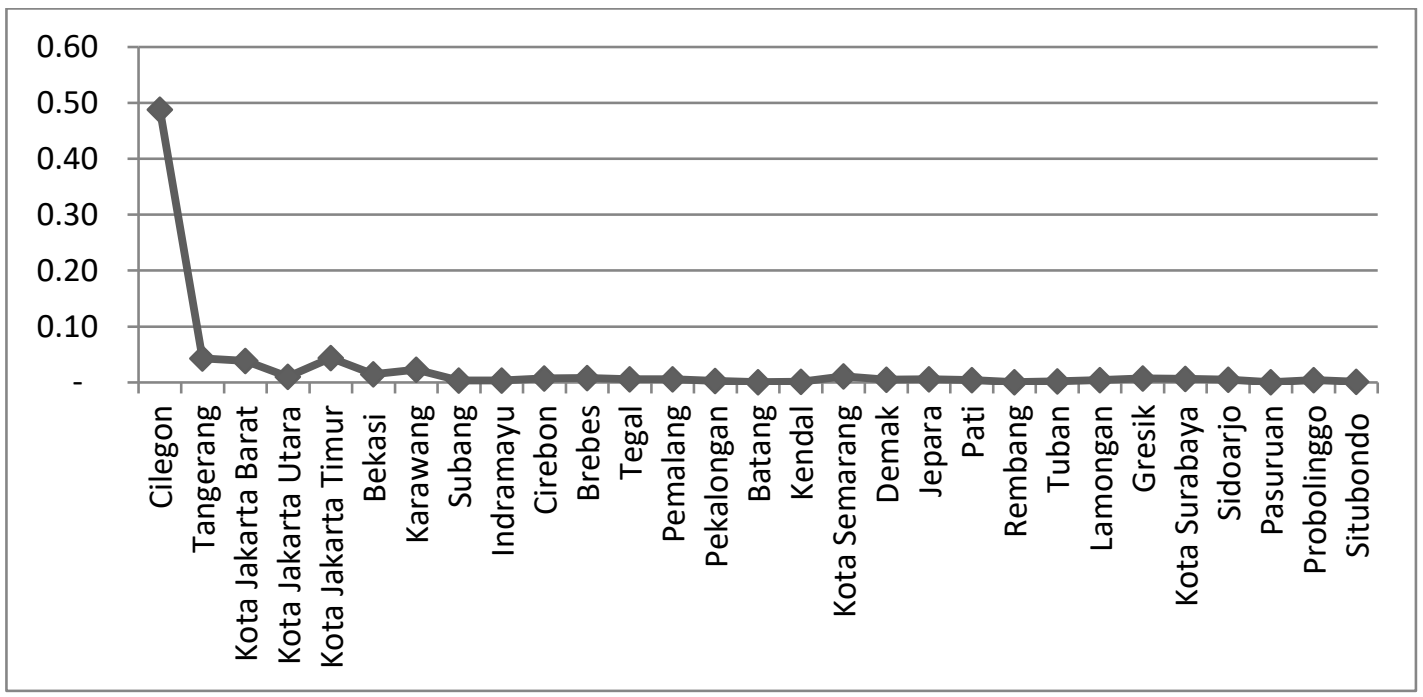

Sumber : Data diolah, 2016

\section{Gambar 2. Grafik Indeks Entropi Theil Daerah Pesisir Utara Pulau Jawa, 2016}

Berdasarkan Gambar 2 dapat diketahui bahwa rata-rata nilai Indeks Entropi Theil adalah 0,0261 yang mendekati 0 berarti ketimpangan atau disparitas ekonomi antarwilayah daerah pesisir utara Pulau Jawa tahun 2016 relatif rendah (Mahardiki, 2013). Walaupun terdapat 2 kabupaten yang memiliki nilai Indeks Entropi Theil diatas rata-rata yakni Kabupaten Cilegon dan Tangerang. Di antara keduanya Kabupaten Cilegon lah yang memiliki nilai Indeks Entropi Theil tertinggi di antara kabupaten lainnya di daerah pesisir utara Pulau Jawa yakni sebesar 0,4884. Hal ini disebabkan oleh adanya konsentrasi industri pada wilayah utara Provinsi Banten khususnya Kabupaten Cilegon. Konsentrasi industri yang dimaksud ialah adanya kawasan industri strategis di Kabupaten Cilegon seperti Krakatau Steel yakni pabrik baja yang sudah berdiri sejak tahun 1960. Tidak hanya itu, di kabupaten ini terdapat 17 proyek PMDN dan 92 proyek PMA serta melibatkan 256 orang tenaga kerja asing (Kompas, 2008). Terkonsentrasi Kabupaten Cilegon 
sebagai kawasan industri menyebabkan terpusatnya prasarana transportasi seperti adanya Pelabuhan Penyebrangan Merak dan Jalan Tol Jakarta-Merak. Keberadaan jalan tol Jakarta-Merak di Kabupaten Cilegon disebabkan oleh dekatnya dengan Provinsi DKI Jakarta.

Untuk kabupaten yang memiliki nilai Indeks Entropi Theil paling rendah atau paling merata di daerah pesisir utara Pulau Jawa adalah Kabupaten Pasuruan yaitu sebesar 0,0004. Kabupaten Pasuruan merupakan kawasan industri di Provinsi Jawa Timur sama halnya seperti Kabupaten Cilegon namun pertumbuhan ekonomi di kabupaten Pasuruan cukup stabil dari tahun ke tahun bahkan menduduki yang paling tinggi di Provinsi Jawa Timur. Alhasil pendapatan per kapita Kabupaten Pasuruan cukup tinggi karena kabupaten ini tidak hanya sebagai kawasan industri seperti pabrik rokok HM Sampoerna, pabrik minuman Coca Cola, Pocari Sweat, Nestle dan Ades namun didukung pula oleh sektor pariwisata seperti Penanjakan Gunung Bromo, Taman Safari Indonesia Prigen, Masjid Cheng Hoo, Gunung Arjuna Welirang dan Kebun Raya Purwodadi dan industri menengah seperti Bakpao Telo. Selain itu terdapat UMKM yang juga berkonstribusi menyokong pertumbuhan ekonomi Kabupaten Pasuruan yakni UMKM makanan bipang dan permen jahe. Seperti yang diketahui sektor pariwisata dan UMKM merupakan sektor yang menetes ke bawah artinya akan berdampak pada penduduk perpendapatan rendah yang memiliki keterampilan rendah.

\subsection{Analisis Hasil Indeks Entropi Theil Daerah Pesisir Selatan Pulau Jawa}

Pada daerah pesisir selatan Pulau Jawa terdapat 23 kabupaten yang berada pada 6 provinsi yakni Banten, DKI Jakarta, Jawa Barat, Jawa Tengah, DI Yogyakarta dan Jawa Timur. Untuk mengetahui pergerakan nilai Indeks Entropi Theil daerah pesisir selatan Pulau Jawa dapat dilihat pada grafik dibawah ini.

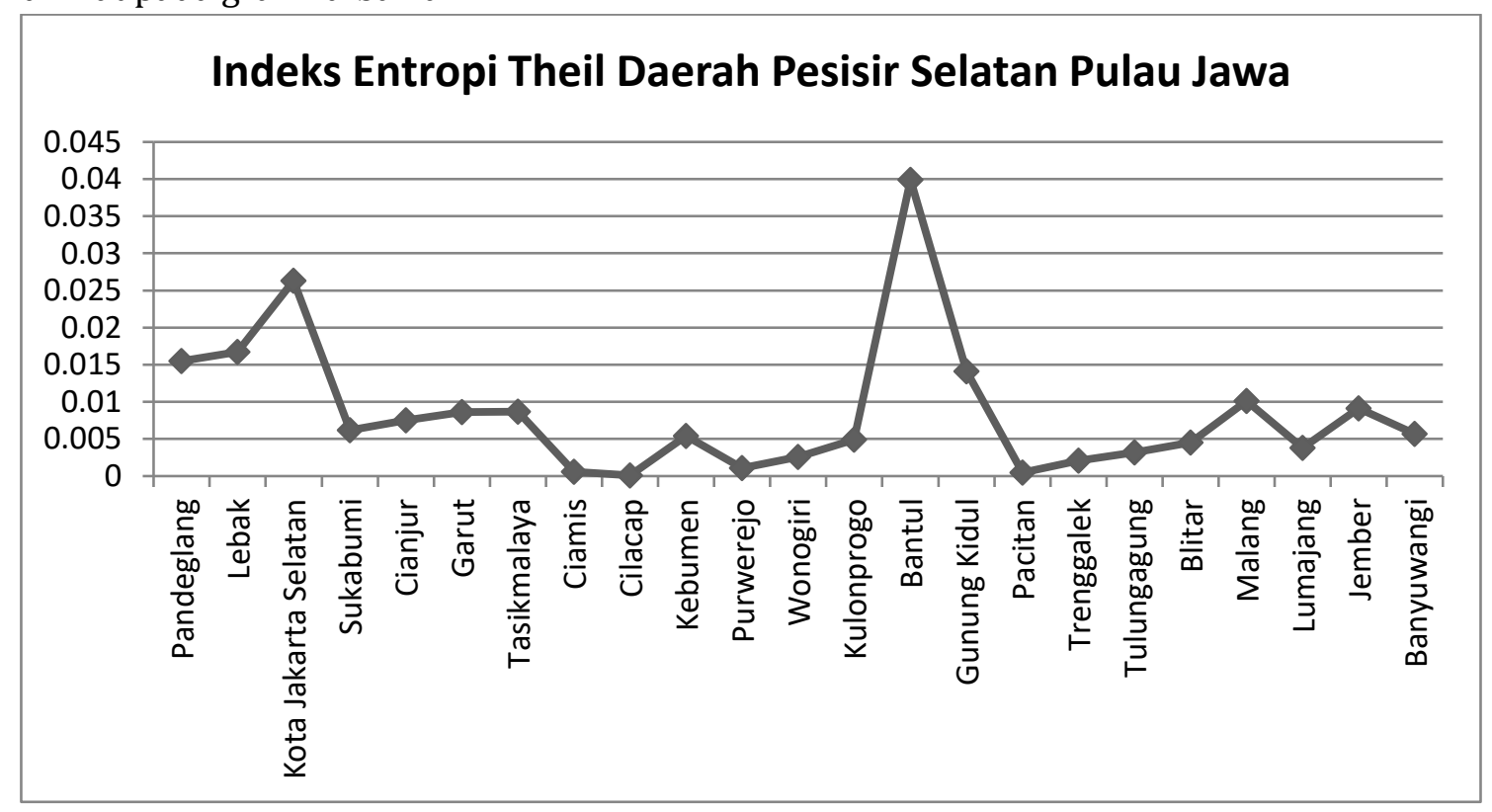

Sumber : Data diolah, 2016

\section{Gambar 3. Grafik Indeks Entropi Theil Daerah Pesisir Selatan Pulau Jawa, 2016}

Berdasarkan grafik diatas dapat diketahui bahwa rata-rata nilai Indeks Entropi Theil daerah pesisir selatan Pulau Jawa ialah 0,0085 yang juga mendekati 0 artinya disparitas ekonomi antarwilayah pesisir selatan Pulau Jawa cukup rendah. Hal ini mengindikasikan bahwa pendapatan 23 kabupaten di pesisir selatan Pulau Jawa dapat dikatakan hampir merata. Diantara 23 kabupaten yang telah disebutkan diatas terdapat kabupaten yang memiliki angka Indeks Entropi Theil tertinggi adalah Kabupaten Bantul sebesar 0,0399 yang berarti ketimpangannya paling tinggi dibanding kabupaten lainnya di daerah pesisir selatan Pulau Jawa. Hal ini 
diakibatkan oleh ketersediaan lapangan kerja pada sektor pertanian dan industri pengolahan yang stagnan (Tempo, 2015). Sektor pertanian dan industri pengolahan untuk menyerap tenaga kerja tidak dikelola dengan serius misalnya industri kreatif sehingga kemiskinan paling banyak menimpa penduduk yang bekerja pada sektor pertanian. Selain itu ketimpangan ekonomi yang terjadi di Kabupaten Bantul karena adanya kesenjangan diperkotaan dan pedesaan terkait akses air minum, kesehatan dan ekonomi (Raharjo, 2018).

Kemudian kabupaten yang memiliki Indeks Entropi Theil terendah di daerah pesisir selatan Pulau Jawa adalah Cilacap sebesar 0,0001. Hal ini dikarenakan PDRB per kapita Kabupaten Cilacap adalah tertinggi di Provinsi Jawa Tengah. Tingginya pendapatan per kapita ini disebabkan oleh andil dari perusahaan berskala besar seperti PT Pertamina UP IV, PT Holcim Tbk, PT Sinar Mas Agro Resources and Technology dan PT Panganmas Inti Persada. Selanjutnya andil perusahaan-perusahaan tersebut mendorong pertumbuhan ekonomi Kabupaten Cilacap menjadi salah satu kabupaten besar yang tumbuh di wilayah Indonesia. Selain itu Kabupaten Cilacap memiliki infrastruktur yang strategi yakni Pelabuhan Internasional Tanjung Intan. Pelabuhan ini merupakan dermaga yang digunakan oleh Pelindo III sebagai gerbang logistik pengangkutan laut penting di bagian selatan Pulau Jawa karena terhubung oleh jalur darat yakni jaringan darat dan rel kereta api serta Bandara Tunggul Wulung (Satelitpost, 2018).

\subsection{Analisis Disparitas Ekonomi dengan Indeks Enthropy Theil Pada Daerah Pesisir Selatan dan Utara Pulau Jawa}

Setelah diketahui rata-rata nilai Indeks Entropi Theil diatas maka dapat disimpulkan bahwa angka Indeks Entropi Theil daerah pesisir utara Pulau Jawa lebih tinggi dibandingkan daerah pesisir selatan seperti pada tabel sebagai berikut.

Tabel 1. Perbandingan Rata-rata Nilai Indeks Entropi Theil Daerah Pesisir Utara dan Selatan Pulau Jawa

\begin{tabular}{|c|l|c|}
\hline No. & \multicolumn{1}{|c|}{ Daerah Pesisir Pulau Jawa } & Indeks Enthropy Theil \\
\hline 1 & Utara & 0,0261 \\
\hline 2 & Selatan & 0,0085 \\
\hline
\end{tabular}

Sumber : Data diolah, 2016

Angka Indeks Entropi Theil daerah pesisir utara Pulau Jawa lebih besar daripada daerah pesisir selatan yakni 0,0261 > 0,0085 yang berarti daerah pesisir selatan lebih merata daripada pesisir utara. Hal ini disebabkan oleh terselesaikannya beberapa pembangunan infrastruktur beberapa tahun belakangan ini diantaranya Jalur Lintas Selatan Jawa Timur dan New Yogyakarta International Airport. Keberadaan jalur lintas selatan sangat berimbas pada perekonomian kawasan selatan yakni perikanan, pertambangan emas dan pariwisata (Warda, 2013). Selain itu kebijakan pemerintah turut andil dalam rendah angka ketimpangan di daerah pesisir selatan Pulau Jawa Seperti pengembangan agrobsinis dengan basis padat karya agar dapat meningkatkan daya saing dari komoditi yang dihasilkan. Lalu dari sisi pembangunan, adanya pelabuhan ikan yang cukup besar di Kabupaten Trenggalek yaitu Pelabuhan Perikanan Nusantara (PPN) di Pantai Prigi.

Bagi daerah pesisir utara Pulau Jawa yang menyebabkan angka ketimpangan lebih tinggi dari daerah pesisir utara Pulau Jawa adalah terlalu terkonsentrasinya aktivitas ekonomi pada sebagian kota besar di pesisir utara Pulau Jawa seperti Kota Surabaya dan Kota Semarang (Warda, 2013). Selain itu, semakin terindustrialisasinya kota atau kabupaten yang terletak di pesisir utara Pulau Jawa maka semakin bebas dan modern perdagangan yang terjadi termasuk banyaknya pihak asing yang turut menjadi pelaku industri di wilayah pesisir Pulau Jawa. Jika terus dibiarkan maka pembagian kue ekonomi tidak lagi timpang karena dinikmati masyarakat kaya Indonesia namun timpang karena dikuasai asing. 


\subsection{Uji Kolmogorov-Smirnov}

Uji Kolmogorov-Smirnov dilakukan untuk membandingkan rangkaian data pada sampel terhadap distribusi normal dimana nilai mean dan standar deviasinya sama (Nuryanto, 2018).

Tabel 2. Hasil Kolmogorov-Smirnov Indeks Entropi Theil Daerah Pesisir Utara dan Selatan Pulau Jawa

\begin{tabular}{lcc}
\hline \multicolumn{1}{c}{ Variabel } & Kolmogorov-Smirnov Z & Keterangan \\
\hline IET Utara & 0,3863 & Distribusi Normal \\
\hline IET Selatan & 0,2171 & Distribusi Tidak Normal \\
\hline
\end{tabular}

Sumber : Data diolah, 2016

Hasil uji normalitas pada Indeks Entropi Theil daerah pesisir utara menerima $\mathrm{H}_{0}$ karena nilai Kolmogorov-Smirnov Z lebih besar dari nilai tabel sehingga data terdistribusi normal. Sedangkan untuk Indeks Entropi Theil daerah pesisir selatan, uji normalitas menyatakan menolak $\mathrm{H}_{0}$ karena nilai Kolmogorov-Smirnov Z lebih kecil dari nilai tabel sehingga data terdistribusi tidak normal. Oleh karena itu, data Indeks Entropi Theil daerah pesisir selatan diubah ke dalam bentuk lain seperti logaritma agar dapat dilakukan uji paires sample t-test.

\subsection{Uji Paired Sample T-test}

Uji paired sample t-test dilakukan untuk membandingkan selisih dua mean dari dua sampel yang berpasangan dengan asumsi data terdistribusi normal (Advernesia, 2019). Sampel berpasangan merupakan subjek yang sama namun mengalami perlakuan yang berbeda. Berikut telah dilakukan uji paired sample t-test dengan hasil pada tabel dibawah.

Tabel 3. Hasil Paired Sample T-test Indeks Entropi Theil Daerah Pesisir Utara dan Selatan Pulau Jawa

\begin{tabular}{lccc}
\hline \multicolumn{1}{c}{ Variabel } & t-statistik & Probabilitas & Keterangan \\
\hline IET Utara & 1,71 & 0,08 & Tidak Ada Perbedaan \\
\hline IET Selatan & 2,05 & 0,17 & Tidak Ada Perbedaan \\
\hline
\end{tabular}

Sumber : Data diolah, 2016

Berdasarkan hasil olah data diatas diperoleh bahwa ketimpangan antara daerah pesisir utara dan selatan Pulau Jawa menunjukkan tidak ada perubahan ketimpangan yang signifikan. Hal ini didapat dari nilai probabilitas Indeks Entropi Theil daerah pesisir utara dan selatan diatas 0,05 sehingga tidak terdapat perbedaan.

\section{KESIMPULAN}

Berdasarkan hasil perhitungan Indeks Entropi Theil diketahui bahwa rata-rata nilai Indeks Entropi Theil daerah pesisir utara Pulau Jawa sebesar 0,0261 dan daerah pesisir selatan sebesar 0,0085. Hal ini berarti nilai Indeks Entropi Theil daerah pesisir selatan Pulau Jawa lebih kecil dari daerah pesisir utara sehingga menunjukkan bahwa pada tahun 2016 daerah pesisir selatan lebih merata daripada pesisir utara Pulau Jawa.

\section{UCAPAN TERIMA KASIH}

Terima kasih saya ucapkan kepada Lembaga Penelitian Universitas AMIKOM Yogyakarta yang telah memberikan hibah penelitian kepada penulis. Tidak lupa saya sampaikan kepada Dekan Fakultas Ekonomi dan Sosial serta Ketua Program Studi Ekonomi yang telah memberikan dukungan atas terselesaikannya penelitian ini.

\section{DAFTAR PUSTAKA}


Advernesia. 2019. Cara Uji Paired Sample $\mathrm{T}$ Test dengan SPSS dan Contohnya. https://www.advernesia.com/blog/spss/cara-uji-paired-sample-t-test-dengan-spss-dancontohnya

BPS. 2019. Gini $2002-2019$. https://www.bps.go.id/dynamictable/2017/04/26/1116/gini-ratio-provinsi-20022019.html

Christofakis, Manolis, Eleni Gaki, Dimitrios Lagos. 2019. The Impact of Economic Crisis on Regional Disparities and The Allocation of Economic Branches in Greek Regions. Bulletin of Geography, Socio-Economic Series. 44, 7-21

Kompas. (2008). Keunggulan dan Ketertingglan "Menetap" di Banten. https://megapolitan.kompas.com/read/2008/01/20/10092541/KEUNGGULAN.DAN.KETE RTINGGALAN.MENETAP.DI.BANTEN?page=all

Mahardiki, Doni dan Rokhedi Priyo Santoso. 2013. Analisis Perubahan Ketimpangan Pendapatan dan Pertumbuhan Ekonomi Antar Propinsi di Indonesia 2006-2011. JEJAK Journal of Economics and Policy. 6 (2), 103-213

Miranti, Ayu. 2017. Mengenal Jalur Pantura, Si Penentu Perekonomian Pulai Jawa. https://www.merdeka.com/jakarta/mengenal-jalur-pantura-si-penentu-perekonomianpulau-jawa.html

Narutomo, Aryo. 2015. Merancang Penelitian - State of The Arts. http://aryonurutomo.blogspot.com/2015/08/merancang-penelitian-state-of-art.html

Nugroho, Thomas. 2004. Disparitas Pembangunan Wilayah Pesisir Utara dan Selatan Jawa Barat (Studi Kasus di Kabupaten Karawang Subang - Garut Ciamis). Tesis. Sekolah Pascasarjana Institus Pertanian Bogor.

Nuryanto, $\quad$ Anjar. $2018 . \quad$ Kolmogorov Smirnov. https://www.academia.edu/4601961/Kolmogorov_Smirnov

Ohlan. Ramphul. 2013. Pattern of Regional Disparities in Socio-economic Development in India: District Level Analysis. Institute of Management Studies and Research, Maharshi Dayanand University. 114, 841-873.

Raharjo, Edzan. 2018. Tingkat Kesenjangan Ekonomi di DIY Lebih Tinggi Dari Nasional. https://news.detik.com/berita-jawa-tengah/d-3797700/tingkat-kesenjangan-ekonomi-didiy-lebih-tinggi-dari-nasional

Satelitpost. 2018. Revitalisasi Pelabuhan Tanjung Intan, Tiga Kapal Besar Bisa Bersandar. https://satelitpost.com/regional/revitalisasi-pelabuhan-tanjung-intan-tiga-kapal-besarbisa-bersandar

Sjafrizal. 2018. Analisis Ekonomi Regional dan Penerapannya di Indonesia. Depok : PT Raja Grafindo Persada. 
70 | Bina Ekonomi

Tempo. 2015. BPS Ungkap Kesenjangan Ekonomi di Yogyakarta Tinggi. https://nasional.tempo.co/read/727170/bps-ungkap-kesenjangan-ekonomi-diyogyakarta-tinggi

The World Bank. 2015. Indonesia's Rising Divide. https://www.worldbank.org/en/news/feature/2015/12/08/indonesia-rising-divide

Tjoe, Yenny. 2018. Pertumbuhan ekonomi selama 20 tahun hanya dinikmati orang kaya. Seberapa parah ketimpangan di Indonesia? https://theconversation.com/pertumbuhan-ekonomi-selama20-tahun-hanya-dinikmati-orang-kaya-seberapa-parah-ketimpangan-di-indonesia-102107

Warda. 2013. Analisis Ketimpangan Pembangunan Ekonomi Antara Wilayah Utara dan Selatan Provinsi Jawa Timur. UNNES Journal. 